\title{
Comparative foraging ecology of a tropical seabird community of the Seychelles, western Indian Ocean
}

\author{
Teresa Catry ${ }^{1, *}$, Jaime A. Ramos ${ }^{1}$, Sébastien Jaquemet ${ }^{2}$, Lucie Faulquier $^{2}$, \\ Maud Berlincourt ${ }^{2}$, Antoine Hauselmann ${ }^{2}$, Patrick Pinet ${ }^{2}$, Matthieu Le Corre ${ }^{2}$ \\ ${ }^{1}$ Institute of Marine Research (IMAR), Department of Zoology, University of Coimbra, 3004-517 Coimbra, Portugal \\ ${ }^{2}$ Laboratoire ECOMAR, Université de la Réunion, 15 avenue René Cassin, BP 7151, 97715 Saint Denis, Réunion Island, France
}

\begin{abstract}
We studied the foraging ecology of a tropical seabird community in 2 islands of the Seychelles from 2005 to 2007. Chick dietary samples were used to compare feeding habits among species and assess inter-annual and seasonal variations in diet. Fish prey dominated the diet of the community (68 to $100 \%$ of prey consumed), although cephalopods were present in $61.3,40.0,27.1$ and $32.9 \%$ of the food samples from white-tailed tropicbirds, sooty terns, brown noddies and wedgetailed shearwaters, respectively. We found high diet overlap between species (Mullidae fish being the first prey consumed [30 to $90 \%$ ] for all species except for the white-tailed tropicbird [<2\%]) but some segregation in prey length. Other important prey were Exocoetidae, Carangidae, Scombridae and Clupeidae mainly for white-tailed tropicbirds, sooty terns and brown noddies, Hemiramphidae and Coryphaenidae for white-tailed tropicbirds, and Engraulidae and fish larvae for lesser noddies and Audubon's shearwaters. Despite some inter-annual and seasonal variations in diet, these were not consistent within the community. Responses of the seabird community to an environmental perturbation that negatively affected chick growth and breeding success of lesser noddies emphasised the higher vulnerability of species with smaller foraging ranges and/or with lower ability to switch diet (lesser noddy, roseate tern) compared to less range-restricted and/or more opportunistic ones (white-tailed tropicbird, brown noddy, sooty tern, white tern). Although situated in a tropical region, the food availability in the Seychelles seems to be predictable at a large (annual) temporal scale, but highly unpredictable at a small (intra-seasonal or daily) temporal scale.
\end{abstract}

KEY WORDS: Tropical seabirds · Foraging ecology · Diet · Temporal variations · Food shortage Western Indian Ocean

Resale or republication not permitted without written consent of the publisher

\section{INTRODUCTION}

The study of the adaptations of seabirds to the unpredictability of their food resources is a central theme in seabird ecology (Ashmole 1971, Diamond 1978, Furness \& Birkhead 1984, Ramos et al. 2002, Weimerskirch 2007), especially in tropical oceans where productivity is lower, prey more patchily distributed and food resources show less seasonal variation compared with temperate or polar environments (Harrison \& Seki 1987, Weimerskirch 2007). Tropical seabirds have developed specific morphological and behavioural adaptations to exploit food resources in such environments. Because wing morphology of tropical seabirds is adapted for efficient flight (in order to search large areas for food) and not for diving, most species are incapable of exploiting the water column when foraging (Spear et al. 2007). Thus, one of the most important foraging strategies of tropical seabirds is to feed in multi-species flocks in association with shoals of predatory fishes (mainly tunas) which drive prey to the surface, making them available to the birds (Ballance \& Pitman 1999, Jaquemet et al. 2004). Studies focusing on the diet composition of entire seabird communities are crucial to understanding many aspects of the foraging ecology of seabirds, such as 
where they go to feed, foraging site fidelity, trip duration, energetic considerations and potential competition for food resources. It is also important for the comparative interpretation and understanding of the trophic relationships between seabirds and the marine environment.

In tropical environments, many seabird species are non-seasonal (breeding all year round) or protracted breeders, which is generally thought to be the consequence of the non-seasonal distribution of food resources (Shealer 2001). An exception to this non-seasonal environmental pattern is found in the central islands of the Seychelles archipelago, western Indian Ocean, where the monsoon climate provides distinct seasonality in food resources throughout the year (Monticelli et al. 2007). In this tropical area, $90 \%$ of all seabirds breed during the same season (Fishpool \& Evans 2001), although 4 out of the 9 species are nonseasonal breeders (Bowler et al. 2002). We studied the foraging ecology of the seabird community of 2 neighbouring islands, Aride and Cousin, in the Seychelles archipelago from 2005 to 2007 . The islands hold large and diverse communities of seabirds, including Procellariiformes, Pelecaniformes and Charadriiformes (Bowler et al. 2002). The main goals of the present study were to (1) characterise the diet of the seabirds of Aride and Cousin Islands and describe inter-annual and seasonal variations in their feeding habits, (2) assess overlap in diet composition and prey size among species and (3) characterise foraging behaviour of each species based on data of diet and chick feeding schedules. Previous studies of tropical seabird communities suggest that, despite the high diversity of prey consumed, seabird diet is mostly dominated by a few prey groups, namely Exocoetidae (flyingfish), Mullidae (goatfishes), Carangidae (trevallies) and cephalopods (Ashmole \& Ashmole 1967, Diamond 1983, Harrison et al. 1983, Surman \& Wooller 2003, Spear et al. 2007). Some of these studies also suggested that tropical seabirds partition resources by exploring different foraging areas (at different foraging ranges) and/or by segregating their diet on the basis of prey size (Diamond 1983, Harrison et al. 1983, Surman \& Wooller 2003). Despite the assumption of non-seasonal distribution in food resources, inter-annual and seasonal variations in the diet of entire tropical seabird communities have been poorly investigated.

In the present study, we provide data on the diet and foraging ecology of an important tropical seabird community, and make comparisons with those available for other tropical communities. This enabled us to assess which foraging characteristics are shared by tropical seabird communities and discuss the unpredictability of food resources for seabirds inhabiting tropical environments.

\section{MATERIALS AND METHODS}

Study area. The main islands of the Seychelles archipelago in the western Indian Ocean are situated on a continental shelf - the Seychelles Bank (defined as the 'plateau') - where depths of 44 to $65 \mathrm{~m}$ extend for about $43000 \mathrm{~km}^{2}$ (Braithwaite 1984; our Fig. 1). The present study was carried out on Aride $\left(4^{\circ} 10^{\prime} \mathrm{S}\right.$, $\left.55^{\circ} 40^{\prime} \mathrm{E}\right)$ and Cousin $\left(4^{\circ} 20^{\prime} \mathrm{S}, 55^{\circ} 40^{\prime} \mathrm{E}\right)$ islands, 2 of the northern granitic islands of the Seychelles, situated $10 \mathrm{~km}$ apart. The climate is seasonal, with hot and wet northwesterly winds between November and March (NW monsoon), and dryer, less hot southeasterly winds between May and September (SE monsoon).

Seabird community. The seabird communities of Aride and Cousin islands include species that forage in a range-gradient between inshore and offshore (from inshore to offshore: roseate tern Sterna dougallii, lesser noddy Anous tenuirostris, white tern Gygis alba, brown noddy Anous stolidus, Audubon's shearwater Puffinus lherminieri, sooty tern S. fuscata, white-tailed tropicbird Phaethon lepturus and wedge-tailed shearwater Puffinus pacificus; Bailey 1968, Feare 1981, Diamond \& Prŷs-Jones 1986, Schreiber \& Burger 2001, authors' pers. obs.). Inshore species include those that forage exclusively within the limits of the 'plateau' and at short distances $(<50 \mathrm{~km})$ from the colony (roseate terns), whereas offshore species are those that forage mainly in the deeper waters outside the 'plateau' and preferentially at larger distances $(>300 \mathrm{~km})$ from the colony (sooty terns, white-tailed tropicbirds and wedge-tailed shearwaters; authors' unpubl. data). Species that have foraging ranges between those of inshore and offshore species are designated intermediate foraging species. The majority of these species forage mainly in large mono- or multi-species flocks associated with shoals of predatory fishes (Feare 1981, Jaquemet et al. 2004). White terns feed both solitarily and in flocks and only the white-tailed tropicbird forages mostly solitarily (Feare 1981, Jaquemet et al. 2004, authors' pers. obs.).

White-tailed tropicbird, white tern and Audubon's shearwater breed all year round on both Aride and Cousin islands. Brown and lesser noddies breed almost exclusively during the SE monsoon and wedge-tailed shearwater during the NW monsoon on both islands. Sooty and roseate terns breed only on Aride Island during the SE monsoon.

Food sample collection and analysis. Food samples of wedge-tailed shearwater, white-tailed tropicbird, brown noddy, lesser noddy and sooty tern were obtained by inducing chicks to regurgitate (chicks regurgitated spontaneously when handled or were encouraged to regurgitate by massaging the abdomen and holding the bird upside down). Samples from 


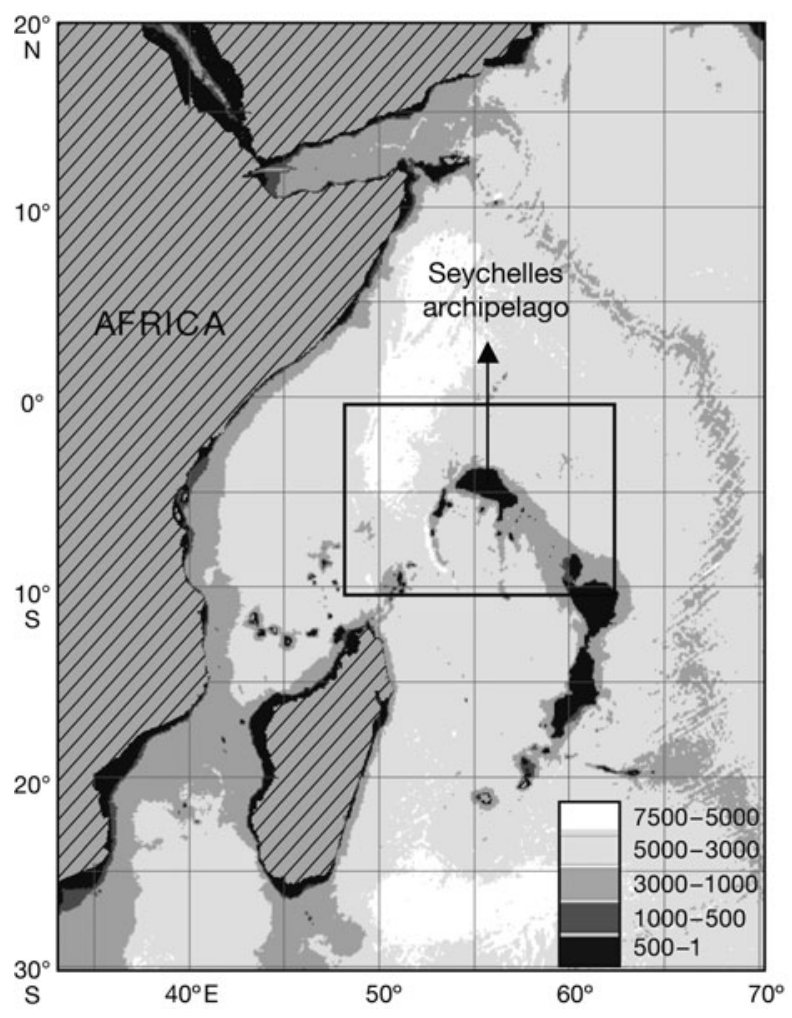

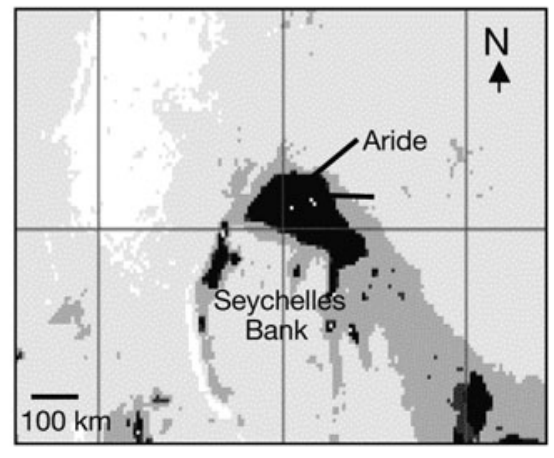

Fig. 1. Study area, Aride and Cousin islands in the Seychelles archipelago, with bathymetric details (depth in $\mathrm{m}$ )

Audubon's shearwater and from some wedge-tailed shearwater chicks were obtained using the stomach flush technique (Duffy \& Jackson 1986). Each chick was sampled only once.

The number of samples collected for each species, island, year and season are presented in Table 1. For Audubon's shearwater, during the analysis process, data from different seasons were pooled for each island because of small sample sizes. Food samples were frozen and returned to the Laboratory of Marine Ecology (ECOMAR), University of La Réunion, for analysis. Each sample was processed in order to determine (1) total wet mass, (2) number of prey per category (fish, cephalopods and crustaceans) and (3) wet mass of each category. Fish items were identified to the lowest possible taxa, using Smith \& Heemstra (1986) and our own reference collection. We measured total length (TL), standard length (SL), fork length (FL), caudal length (CL) and fresh mass (M) of all intact fish (see Smith \& Heemstra 1986 for fish morphology). We were then able to determine the allometric relationships between TL and any other biometric measurements for the main fish prey items. We used these equations to estimate TL (hereinafter prey length) of partially digested items (Diamond 1983).

The diet of roseate and white tern chicks was studied by performing systematic observations of chick food provisioning on Aride Island (Table 1). Adult roseate and white terns carry their prey in the bill, which
Table 1. Puffinus lherminieri, P. pacificus, Anous tenuirostris, A. stolidus, Sterna fuscata, Gygis alba, S. dougallii and Phaethon lepturus. Number of food samples collected and number of chicks monitored on Aride Island, used to estimate chick feeding schedules. For food samples, data for white and roseate terns refer to the number of prey recorded through observations of chick feeding. Season refers to the monsoon season. AS = Audubon's shearwater, WTS = wedge-tailed shearwater, LN = lesser noddy, $\mathrm{BN}=$ brown noddy, $\mathrm{ST}=$ sooty tern, $\mathrm{WT}=$ white tern, $\mathrm{RT}=$ roseate tern, $\mathrm{WTT}=$ white-tailed tropicbird

\begin{tabular}{|lccccccccc|}
\hline Season & AS & WTS & LN & BN & ST & WT & RT & WTT \\
\hline $\begin{array}{l}\text { Diet composition: food samples } \\
\text { Aride Island }\end{array}$ & 0 & 0 & 52 & 49 & 54 & 89 & 0 & 33 \\
SE 2005 & 0 & 0 & & & & \\
NW 2006 & 0 & 0 & 0 & 0 & 0 & 160 & 0 & 20 \\
SE 2006 & 0 & 0 & 38 & 48 & 50 & 88 & 0 & 34 \\
NW 2007 & 15 & 30 & 0 & 0 & 0 & 187 & 0 & 38 \\
SE 2007 & 13 & 0 & 50 & 44 & 51 & 96 & 221 & 24 \\
Total Aride & 28 & 30 & 140 & 141 & 155 & 620 & 221 & 149 \\
Cousin Island & & & & & & & & \\
SE 2005 & 4 & 0 & 24 & 29 & 0 & 0 & 0 & 34 \\
NW 2006 & 0 & 39 & 0 & 0 & 0 & 0 & 0 & 0 \\
SE 2006 & 5 & 0 & 25 & 0 & 0 & 0 & 0 & 32 \\
NW 2007 & 0 & 0 & 0 & 0 & 0 & 0 & 0 & 23 \\
SE 2007 & 23 & 0 & 31 & 33 & 0 & 0 & 0 & 46 \\
Total Cousin & 32 & 39 & 80 & 62 & 0 & 0 & 0 & 145 \\
Chick feeding schedules: chick samples & & & \\
Aride Island & & & & & & & & \\
SE 2005 & 0 & 0 & 20 & 18 & 19 & 0 & 0 & 18 \\
NW 2006 & 0 & 0 & 0 & 0 & 0 & 0 & 0 & 21 \\
SE 2006 & 0 & 0 & 18 & 22 & 18 & 0 & 0 & 19 \\
NW 2007 & 0 & 0 & 0 & 0 & 0 & 0 & 0 & 15 \\
SE 2007 & 0 & 0 & 16 & 19 & 0 & 0 & 0 & 17 \\
\hline
\end{tabular}


allows its identification at the time of delivery. Given that previous studies have already examined the diet of roseate terns on Aride Island (Ramos 2000, Monticelli et al. 2008), we collected data for this species only during the SE monsoon of 2007. For each feeding event of white and roseate terns, we identified the prey (mostly at the family level) and recorded their length in relation to adult bill length $(1 / 4,1 / 2,3 / 4$, etc. $)$, which is $40.29 \pm 2.26 \mathrm{~mm}$ and $38.03 \pm 1.62 \mathrm{~mm}$ in white terns and roseate terns, respectively (mean $\pm \mathrm{SD} \mathrm{T}$. Catry \& J. A. Ramos unpubl. data).

For all seabird species, the majority of chicks were sampled during the linear growth phase (lesser noddy: 5 to $19 \mathrm{~d}$ [Ramos et al. 2004], brown noddy [Ramos et al. 2006] and sooty tern: 8 to $30 \mathrm{~d}$, wedge-tailed shearwater and Audubon's shearwater: 10 to $40 \mathrm{~d}$, whitetailed tropicbird: 10 to $30 \mathrm{~d}$ white tern and roseate tern: 5 to 25 d; T. Catry \& J. A. Ramos unpubl. data).

Seasonal variations in diet composition. Intraseasonal variations in the diet composition of a seabird community are usually difficult to document because changes may occur gradually and asynchronously within the community. However, important changes in diet composition may have direct and evident effects on the breeding performance of some species and then be more easily documented. Lesser noddies have been previously described as one of the most sensitive species to changes in food availability within this seabird community (Ramos et al. 2004). We monitored growth and survival of lesser noddy chicks on Aride Island in order to detect periods of environmental perturbations that negatively affected this species. To detect periods of poor chick growth, samples of 52,59 and 53 chicks were weighed daily or every $2 \mathrm{~d}$ between July and August (SE monsoon) of 2005, 2006 and 2007, respectively. Most chicks were weighed from hatching until at least the end of the linear growth period (19 d, Ramos et al. 2004), but smaller subsamples of chicks $(10,17$ and 16 in 2005, 2006 anfd 2007, respectively) were weighed until 30 to $40 \mathrm{~d}$ of age. These data were used to calculate linear growth rates (LGR $=$ slope of the regression line of mass on age during the linear growth period). All nests were monitored until the end of the breeding season in order to estimate chick survival. In 2006, an environmental perturbation negatively affected the growth and fledging success of lesser noddy chicks on Aride Island (see 'Results'). We compared the diet of lesser noddies and of 4 other species (brown noddies, sooty terns, white terns and white-tailed tropicbirds) before and during this period.

Chick feeding schedules. We studied chick feeding schedules in 4 species in order to characterise and compare temporal patterns of feeding activities. On Aride Island, chick samples (Table 1) of white-tailed tropicbird, brown noddy, lesser noddy and sooty tern were weighed at regular intervals during 5 to $7 \mathrm{~d}$ in order to assess chick feeding schedules. Brown noddies and sooty terns were weighed every 6 h (06:00, 12:00, 18:00 and 24:00 h) and tropicbirds and lesser noddies were weighed every 5 h (06:00, 11:00, 16:00 and 21:00 h). No weighing was carried out during the night (between 21:00 and 06:00 h) for the latter 2 species, given that previous studies have already shown that chicks are not fed in that period on Aride Island (Ramos \& Pacheco 2003, Ramos et al. 2004). We considered that a feeding event took place whenever there was an increment in chick mass between 2 weighing periods.

Data analysis. Diet composition is expressed both as frequency of occurrence, calculated as the percentage of regurgitations containing a given prey taxon, and numerical frequency, defined as the percentage of individuals of each prey taxon in 1 sample relative to all individuals in the same sample. For roseate tern and white tern, only numerical frequencies are presented. A principal component analysis (PCA) was performed to describe patterns in the diet of the seabird community between islands, species, years and seasons. The specific numerical frequencies of each prey taxon (prey family) in each island and in each studied season or year were used as factors. The use of frequencies of occurrence in the PCA produced similar results and thus we opted to present only the analysis with numerical frequencies. Overlap in diet composition between the studied seabird species was measured using Horn's modification of Morisita's index (Diamond 1983) and based on the numerical frequency of each prey taxon. An overlap index $>0.6$ was treated arbitrarily as a significant overlap in the diet of the 2 species compared (Diamond 1983).

We used Spearman correlations to assess relationships between mean adult body mass (T. Catry \& J. A. Ramos unpubl. data) and mean prey length and mean wet mass per food sample.

Statistical analyses were performed using STATISTICA version 6.0 (StatSoft 2000). All data are presented as mean $\pm \mathrm{SD}$.

\section{RESULTS}

\section{Diet composition}

We identified 26 species of prey belonging to 18 different families in the diet of the seabird community of Aride and Cousin islands during the whole study period (2005 to 2007; Table 2). The mean number of prey and mean wet mass per food sample was significantly different among species (Kruskal-Wallis 
Table 2. Puffinus lherminieri, P. pacificus, Anous tenuirostris, A. stolidus, Sterna fuscata, Gygis alba, S. dougallii and Phaethon lepturus. Sample and diet composition of the seabird community at Aride and Cousin islands (2005 to 2007). NF = numerical frequency $(\%), F O=$ frequency of occurrence $(\%)$. n.a.: not applicable; - : absence of listed prey items

\begin{tabular}{|c|c|c|c|c|c|c|c|c|c|c|c|c|c|c|}
\hline Prey & \multicolumn{2}{|c|}{$\begin{array}{l}\text { Audubon's } \\
\text { shearwater }\end{array}$} & \multicolumn{2}{|c|}{$\begin{array}{l}\text { Wedge-tailed } \\
\text { shearwater }\end{array}$} & \multicolumn{2}{|c|}{$\begin{array}{l}\text { Lesser } \\
\text { noddy }\end{array}$} & \multicolumn{2}{|c|}{$\begin{array}{l}\text { Brown } \\
\text { noddy }\end{array}$} & \multicolumn{2}{|c|}{$\begin{array}{l}\text { Sooty } \\
\text { tern }\end{array}$} & $\begin{array}{l}\text { White } \\
\text { tern }\end{array}$ & $\begin{array}{l}\text { Roseate } \\
\text { tern }\end{array}$ & \multicolumn{2}{|c|}{$\begin{array}{l}\text { White-tailed } \\
\text { tropicbird }\end{array}$} \\
\hline No. of samples & \multicolumn{2}{|c|}{60} & \multicolumn{2}{|c|}{70} & \multicolumn{2}{|c|}{220} & \multicolumn{2}{|c|}{203} & \multicolumn{2}{|c|}{155} & n.a. & n.a. & \multicolumn{2}{|c|}{284} \\
\hline No. of prey & \multicolumn{2}{|c|}{376} & \multicolumn{2}{|c|}{744} & \multicolumn{2}{|c|}{2345} & \multicolumn{2}{|c|}{1299} & \multicolumn{2}{|c|}{910} & 620 & 221 & \multicolumn{2}{|c|}{1039} \\
\hline $\begin{array}{l}\text { Mean no. of } \\
\text { prey sample }\end{array}$ & \multicolumn{2}{|c|}{$6.7 \pm 6.0$} & $11.2 \pm$ & 12.0 & 10.7 & \pm 8.8 & $6.4 \pm$ & 6.8 & $5.9=$ & $=4.0$ & n.a. & n.a. & 3.6 & 2.4 \\
\hline $\begin{array}{l}\text { Mean no. of } \\
\text { fish sample }\end{array}$ & $6.6 \pm$ & 6.1 & $9.3 \pm$ & 11.8 & 10.6 & \pm 8.8 & $5.7 \pm$ & 6.8 & $4.8=$ & $=4.0$ & n.a. & n.a. & 2.5 & 1.9 \\
\hline $\begin{array}{l}\text { Mean no. of } \\
\text { cephalopods sample }\end{array}$ & $0.2 \pm$ & 0.6 & $1.9 \pm$ & 4.7 & 0.04 & \pm 0.2 & $0.7 \pm$ & 1.8 & $1.0=$ & $=2.0$ & n.a. & n.a. & 1.1 & 1.7 \\
\hline $\begin{array}{l}\text { Mean wet mass } \\
\text { sample }^{-1}\end{array}$ & $11.7 \pm$ & \pm 8.8 & $40.1 \pm$ & 20.2 & 5.5 & \pm 3.2 & $10.8 \pm$ & $=6.6$ & 13.6 & \pm 6.6 & n.a. & n.a. & 41.7 & 19.6 \\
\hline $\begin{array}{l}\text { Mean wet mass as \% } \\
\text { of adult body mass }\end{array}$ & 6.9 & & 10. & & & 39 & 5.6 & & 6. & & n.a. & n.a. & 12 & \\
\hline $\begin{array}{l}\text { Mean wet mass of } \\
\text { fish sample }\end{array}$ & $11.7 \pm$ & \pm 8.8 & & & 5.5 & \pm 3.2 & $8.8 \pm$ & 6.4 & 11.0 & \pm 7.2 & n.a. & n.a. & 35.0 & 21.4 \\
\hline $\begin{array}{l}\text { Mean wet mass of } \\
\text { cephalopods sample }^{-1}\end{array}$ & $0.007 \pm$ & \pm 0.04 & & & 0.00 & \pm 0.1 & $2.0 \pm$ & 4.3 & $2.6=$ & $=4.9$ & n.a. & n.a. & $6.8 \pm$ & 11.5 \\
\hline Minimum no. of & 5 & & 8 & & & 0 & 12 & & 1 & & 15 & 8 & 1 & \\
\hline & NF & $\mathrm{FO}$ & NF & $\mathrm{FO}$ & NF & $\mathrm{FO}$ & NF & $\mathrm{FO}$ & NF & $\mathrm{FO}$ & NF & NF & NF & $\mathrm{FO}$ \\
\hline Fish & 97.3 & 100.0 & 82.5 & 97.1 & 99.5 & 100.0 & 89.4 & 90.2 & 82.3 & 94.2 & 93.5 & 100.0 & 68.5 & 94.4 \\
\hline Balistidae & & & & & & & & & & & & & & \\
\hline $\begin{array}{l}\text { Unidentified Balistidae } \\
\text { Belonidae }\end{array}$ & - & - & - & - & - & - & - & - & - & - & - & - & 0.1 & 0.4 \\
\hline Unidentified Belonidae & - & - & - & - & - & - & 0.1 & 0.5 & 1.0 & 5.2 & 3.2 & - & 1.1 & 2.8 \\
\hline Caesionidae & & & & & & & & & & & & & & \\
\hline Dipterygonotus balteatus & - & - & 0.7 & 1.4 & 0.1 & 0.5 & 1.9 & 6.9 & 2.0 & 5.2 & 2.1 & 0.9 & 2.5 & 4.2 \\
\hline Caesio caerulaureus & - & - & - & - & - & - & - & - & - & - & - & - & 0.2 & 0.4 \\
\hline Pterocaesio sp. & - & - & - & - & - & - & - & - & - & - & - & - & 0.3 & 0.4 \\
\hline Carangidae & & & & & & & & & & & & & & \\
\hline Decapterus macrosoma & - & - & - & - & - & - & 0.2 & 0.5 & - & - & - & - & 0.8 & 2.5 \\
\hline Decapterus sp. & - & - & - & - & 0.3 & 1.8 & 1.0 & 3.9 & 0.1 & 3.9 & - & - & 4.1 & 9.5 \\
\hline Unidentified Carangidae & 4.3 & 18.3 & 3.9 & 12.9 & 4.7 & 20.0 & 8.5 & 23.2 & 9.3 & 18.7 & 3.9 & 2.3 & 7.0 & 15.5 \\
\hline Clupeidae & & & & & & & & & & & & & & \\
\hline Sardinella sp. & - & - & - & - & - & - & 0.1 & 0.5 & 0.2 & 1.3 & - & - & 0.2 & 0.7 \\
\hline Unidentified Clupeidae & 0.3 & 1.7 & 0.7 & 2.86 & 0.2 & 1.4 & 2.4 & 9.9 & 4.7 & 12.3 & 0.5 & 1.8 & 1.8 & 4.2 \\
\hline Coryphaenidae & & & & & & & & & & & & & & \\
\hline Coryphaena hippurus & - & - & - & - & - & - & - & - & - & - & - & - & 0.1 & 0.4 \\
\hline Coryphaena equiselis & - & - & - & - & - & - & - & - & - & - & - & - & 0.2 & 0.4 \\
\hline Coryphaena sp. & - & - & - & - & - & 0.3 & 1.5 & 0.4 & 2.6 & 0.2 & - & 4.1 & 12.7 & \\
\hline Engraulidae & & & & & & & & & & & & & & \\
\hline Unidentified Engraulidae & 2.4 & 8.3 & - & - & 11.0 & 31.4 & 14.7 & 17.7 & 3.6 & 9.0 & 0.7 & 0.5 & 0.8 & 2.1 \\
\hline Exocoetidae & & & & & & & & & & & & & & \\
\hline Hirundichthys speculiger & $r-$ & - & - & - & 0.1 & 0.9 & 0.2 & 1.5 & 0.2 & 1.3 & - & - & 2.9 & 9.9 \\
\hline Parexocoetus brachypterus & $I S-$ & - & - & - & & & 0.1 & 0.5 & - & - & - & - & 1.3 & 3.9 \\
\hline Parexocoetus sp. & - & - & - & - & 0.04 & 0.5 & 0.2 & 1.5 & - & - & - & - & 0.4 & 1.4 \\
\hline Exocoetus monocirrhus & - & - & - & - & - & - & - & 0.1 & 0.7 & - & - & 0.1 & 0.4 & \\
\hline Exocoetus volitans & - & - & - & - & - & - & - & - & - & - & - & - & 0.1 & 0.4 \\
\hline Exocoetus sp. & - & - & - & - & - & - & - & - & 0.2 & 1.3 & - & - & 1.5 & 2.5 \\
\hline Unidentified Exocoetidae & - & - & 0.5 & 2.9 & 0.2 & 1.8 & 2.4 & 10.3 & 5.7 & 16.1 & 9.2 & 0.5 & 13.0 & 33.5 \\
\hline Hemiramphidae & & & & & & & & & & & & & & \\
\hline $\begin{array}{l}\text { Oxyporhamphus } \\
\text { micropterus }\end{array}$ & - & - & - & - & - & - & 0.2 & 1.0 & 0.1 & 0.7 & - & - & 3.4 & 11.6 \\
\hline Euleptorhamphus viridis & - & - & - & - & - & - & - & - & - & - & - & - & 2.4 & 8.5 \\
\hline $\begin{array}{l}\text { Unidentified } \\
\text { Hemiramphidae }\end{array}$ & - & - & - & - & 0.04 & 0.5 & 0.6 & 2.5 & 0.6 & 2.6 & 2.9 & 0.9 & 4.5 & 13.0 \\
\hline
\end{tabular}


Table 2 (continued)

\begin{tabular}{|c|c|c|c|c|c|c|c|c|c|c|c|c|c|c|}
\hline & NF & $\mathrm{FO}$ & NF & $\mathrm{FO}$ & NF & FO & $\mathrm{NF}$ & $\mathrm{FO}$ & $\mathrm{NF}$ & $\mathrm{FO}$ & $\mathrm{NF}$ & $\mathrm{NF}$ & $\mathrm{NF}$ & $\mathrm{FO}$ \\
\hline \multicolumn{15}{|l|}{ Holocentridae } \\
\hline $\begin{array}{l}\text { Unidentified Holocentridae } \\
\text { Labridae }\end{array}$ & - & - & - & - & - & - & - & - & - & - & 0.5 & - & 0.1 & 0.4 \\
\hline Unidentified Labridae & - & - & - & - & _- & _- & _- & - & - & - & - & - & 0.2 & 0.7 \\
\hline Mullidae & & & & & & & & & & & & & & \\
\hline Mulloidichthys flavolineatus & $5-$ & - & - & 0.2 & 0.9 & 0.5 & 0.5 & - & - & - & - & - & - & \\
\hline $\begin{array}{l}\text { Unidentified Mullidae } \\
\text { Pomacentridae }\end{array}$ & 75.8 & 80.0 & 46.2 & 70.0 & 59.8 & 87.7 & 29.8 & 40.4 & 35.4 & 44.5 & 45.3 & 90.5 & 1.9 & 6.0 \\
\hline $\begin{array}{l}\text { Unidentified Pomacentridae } \\
\text { Scombridae }\end{array}$ & - & - & - & - & - & - & - & - & - & 0.3 & - & 0.2 & 0.7 & - \\
\hline $\begin{array}{l}\text { Unidentified Scombridae } \\
\text { Syngnathidae }\end{array}$ & - & - & 0.9 & 5.7 & 0.9 & 4.6 & 3.2 & 12.8 & 10.2 & 23.2 & 2.1 & 2.7 & 9.0 & 24.7 \\
\hline Unidentified Syngnathidae & - & - & - & - & - & - & - & - & - & - & - & - & 0.1 & 0.4 \\
\hline Fish larvae & 12.8 & 20.0 & 23.1 & 11.4 & 21.3 & 16.4 & 17.2 & 10.8 & 1.0 & 2.6 & 1.9 & - & 0.7 & 0.4 \\
\hline Others & - & - & - & - & - & - & - & - & - & - & 2.4 & - & & \\
\hline Unidentified fish & 1.9 & 8.3 & 21.4 & 6.4 & 0.7 & 4.1 & 5.9 & 11.8 & 5.4 & 14.2 & 18.4 & - & 3.6 & 9.9 \\
\hline $\begin{array}{l}\text { Cephalopod } \\
\text { Teuthida } \\
\text { Crustacea }\end{array}$ & 2.7 & 8.3 & 16.9 & 32.9 & 0.4 & 4.1 & 10.6 & 27.1 & 17.7 & 40.0 & 6.5 & - & 31.2 & 61.3 \\
\hline Unidentified Crustacea & - & - & 0.5 & 4.3 & 0.1 & 0.9 & 0.1 & 0.5 & - & - & - & - & 0.3 & 0.4 \\
\hline
\end{tabular}

$\chi^{2}{ }_{(5)}=179.8, \mathrm{p}<0.001$ and $\chi^{2}{ }_{(5)}=621.4, \mathrm{p}<0.001$, respectively). Wedge-tailed shearwaters and lesser noddies had the highest number of prey items per sample, and white-tailed tropicbirds and wedge-tailed shearwaters showed the heaviest stomach contents (Table 2).

Table 3. Principal component analysis (PCA) for the 14 original diet variables. Eigenvalues, variance explained, cumulative variance and correlation matrix of the original diet variables with the first 4 principal component (PC) axes performed for all seabird species and sampling seasons

\begin{tabular}{|lrrrr|}
\hline & PC1 & PC2 & PC3 & PC4 \\
\hline Eigenvalues & 4.68 & 2.06 & 1.45 & 1.28 \\
Variance explained (\%) & 33.42 & 14.72 & 10.39 & 9.13 \\
Cumulative variance (\%) & 33.42 & 48.14 & 58.53 & 67.66 \\
Variables & & & & \\
Fish & & & & \\
Hemiramphidae & $0.82^{\mathrm{a}}$ & 0.08 & 0.08 & 0.16 \\
Exocoetidae & $0.89^{\mathrm{a}}$ & 0.03 & 0.21 & 0.04 \\
Coryphaenidae & $0.87^{\mathrm{a}}$ & 0.02 & -0.03 & -0.08 \\
Scombridae & 0.40 & $0.59^{\mathrm{a}}$ & -0.08 & 0.16 \\
Carangidae & 0.13 & $0.79^{\mathrm{a}}$ & -0.02 & -0.17 \\
Caesionidae & $0.59^{\mathrm{a}}$ & -0.12 & -0.05 & $-0.53^{\mathrm{a}}$ \\
Mullidae & $-0.87^{\mathrm{a}}$ & -0.11 & 0.03 & -0.05 \\
Engraulidae & -0.24 & -0.17 & $-0.50^{\mathrm{a}}$ & -0.37 \\
Clupeidae & -0.09 & $0.90^{\mathrm{a}}$ & -0.04 & 0.15 \\
Fish larvae & -0.31 & -0.46 & $-0.53^{\mathrm{a}}$ & 0.15 \\
Others & 0.06 & -0.03 & $0.74^{\mathrm{a}}$ & -0.11 \\
Unidentified fish & 0.03 & -0.31 & $0.68^{\mathrm{a}}$ & 0.03 \\
Squid & $0.82^{\mathrm{a}}$ & 0.03 & 0.13 & 0.15 \\
Crustacea & 0.19 & 0.01 & -0.04 & $0.85^{\mathrm{a}}$ \\
aMarked loadings (absolute value) $\geq 0.5$ & & \\
\hline
\end{tabular}

PCA reduced the 14 original variables to 4 independent principal components that explained $67.7 \%$ of the total variance (Table 3 ). The first (PC1) and second (PC2) components alone explained $48 \%$ of the total variance. PC1 was positively correlated with the proportion of Hemiramphidae (halfbeak), Exocoetidae (flyingfish), Coryphaenidae (dolphin fish), Caesionidae (fusiliers) and squid in the diet, and negatively correlated with the occurrence of Mullidae (goatfish). PC2 was positively correlated with the proportion of Clupeidae (sardines), Carangidae (mackerel) and Scombridae (mackerel and tuna; Table 3). Overall, the seabird community was separated into 2 groups along the first axis: white-tailed tropicbird, with a higher proportion of prey such as squid, Exocoetidae, Hemiramphidae, Coryphaenidae and Caesionidae appeared positively correlated with $\mathrm{PC} 1$; all the other species, relying mostly upon Mullidae, were negatively correlated with the first axis (Fig. 2). As expected, diet composition of those species sampled on both islands (see Table 1) was similar between Aride and Cousin islands, with annual and seasonal differences being apparently more important than differences between the 2 islands (Fig. 2). Given the similarities between Aride and Cousin, hereinafter, data for each species are pooled from the 2 islands.

Fish prey largely dominated the diet of the seabirds of Aride and Cousin islands, while cephalopods (squid) constituted an important proportion (frequency of occurrence: 27 to $61 \%$ ) of the diet of 4 of the 8 studied species. White-tailed tropicbirds and roseate terns showed the most and the least diverse diets, respec- 


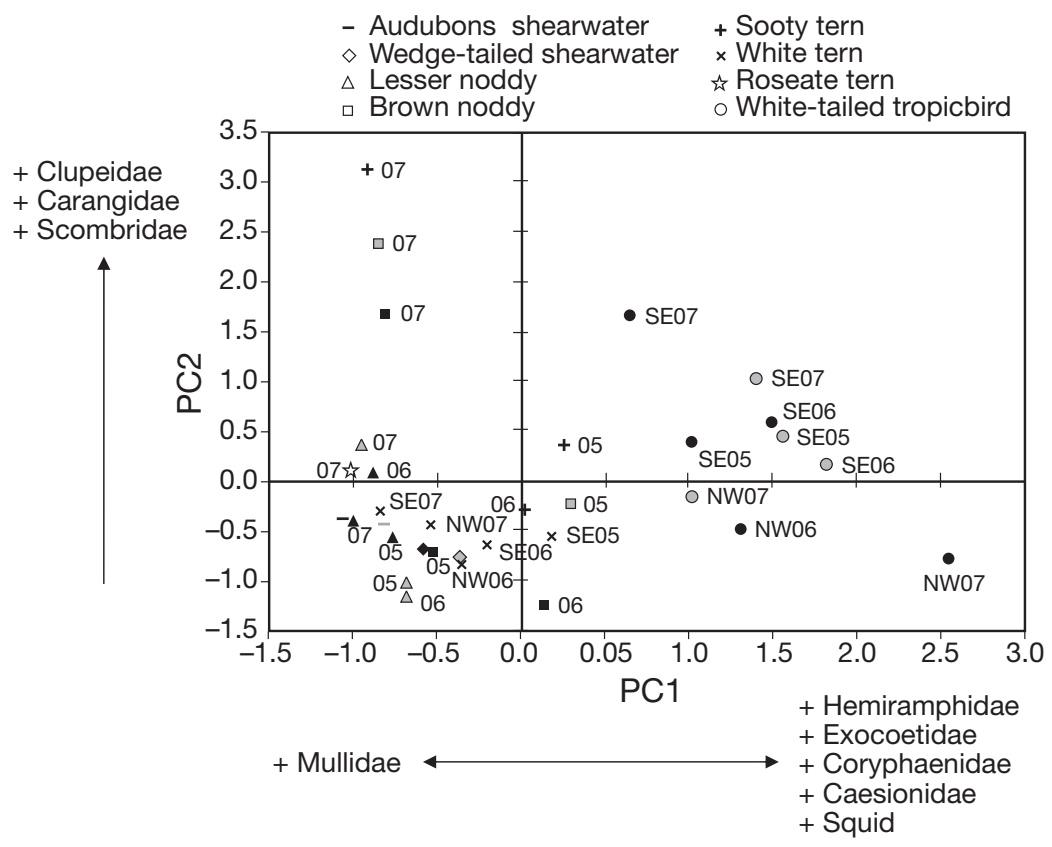

Fig. 2. Puffinus lherminieri, P. pacificus, Anous tenuirostris, A. stolidus, Sterna fuscata, Gygis alba, S. dougallii and Phaethon lepturus. Distribution of the diet scores for each species in each sampling season along the 2 principal component axes (PC1 and PC2). Black symbols (including all + , is and $\times$ ) refer to Aride Island and grey symbols to Cousin Island. SE and NW correspond to the SE and NW monsoons, respectively, and 05, 06 and 07 refer to the years of study (2005, 2006 and 2007, respectively). The first principal component represents a gradient from species with a high proportion of Mullidae in the diet to species that consume higher percentages of Hemiramphidae, Exocoetidae, Coryphaenidae, Caesionidae and squids. The second principal component represents a gradient of increasing consumption of Clupeidae, Carangidae, and Scombridae

tively (Table 2). Fish from the family Mullidae were the most consumed prey, both by number (between 30.3 and $90.5 \%$ ) and by occurrence (between 40.9 and $87.7 \%$ ), by all species with the exception of whitetailed tropicbirds. Ninety percent of the prey consumed by roseate tern chicks were Mullidae and other prey appeared only sporadically. Mullidae were the prey consumed most by white tern chicks, followed by Exocoetidae and squids. Lesser noddies and Audubon's shearwaters preyed mostly upon Mullidae, Carangidae, Engraulidae (anchovies) and unidentified fish larvae, and wedge-tailed shearwaters showed similar diet but with no consumption of Engraulidae and with a higher consumption of cephalopods. Squid figured prominently (frequency of occurrence: $>27 \%$ ) in the diet of 3 other seabird species: brown noddy, sooty tern and white-tailed tropicbird. Exocoetidae, Carangidae, Scombridae and Clupei- dae were commonly found in the regurgitations of brown noddies, sooty terns and white-tailed tropicbirds, whereas Hemiramphidae and Coryphaenidae were frequent only in the diet of whitetailed tropicbirds.

The overlap indices (Morisita-Horn) calculated for every pair of species and based on the number of prey consumed reflect the high similarity in diet composition within the whole seabird community (Table 4). In fact, only the white-tailed tropicbird showed consistently low overlap indices with all other species.

\section{Inter-annual and seasonal variations in diet composition}

The larger inter-annual changes in diet composition of the seabird community were recorded for sooty terns and brown noddies (Fig. 2). However, these changes were not characterised by the consumption of different prey, but mostly by a shift in the proportions of the consumed prey. Indeed, in the SE monsoon of 2007, sooty terns and brown noddies fed their chicks with a higher proportion of Carangidae and Clupeidae and a lower proportion of squid, and brown noddies also consumed a higher proportion of Mullidae (Fig. 2, Table 5). During the same season, white-tailed tropicbirds consumed a larger proportion of Scombridae, but the differences with other years were not as pronounced as for the previous species (Fig. 2, Table 5).

Table 4. Puffinus lherminieri, P. pacificus, Anous tenuirostris, A. stolidus, Sterna fuscata, Gygis alba, S. dougallii and Phaethon lepturus. Morisita-Horn overlap index of dietary composition of the seabird community of Aride and Cousin islands based on numerical frequency of prey. Significant overlap values $(>0.6)$ are presented in bold. See Table 1 for seabird abbreviations

\begin{tabular}{|lcccccccc|}
\hline & AS & WTS & LN & BN & ST & WT & RT & WTT \\
\hline WTS & $\mathbf{0 . 8 6 5}$ & & & & & & & \\
LN & $\mathbf{0 . 9 6 0}$ & $\mathbf{0 . 8 2 8}$ & & & & & & \\
BN & $\mathbf{0 . 6 8 8}$ & $\mathbf{0 . 7 5 3}$ & $\mathbf{0 . 8 1 6}$ & & & & & \\
ST & $\mathbf{0 . 7 1 6}$ & $\mathbf{0 . 7 2 5}$ & $\mathbf{0 . 7 4 2}$ & $\mathbf{0 . 8 5 1}$ & & & & \\
WT & $\mathbf{0 . 8 2 7}$ & $\mathbf{0 . 7 5 1}$ & $\mathbf{0 . 8 2 6}$ & $\mathbf{0 . 7 7 7}$ & $\mathbf{0 . 8 7 4}$ & & & \\
RT & $\mathbf{0 . 9 7 1}$ & $\mathbf{0 . 7 0 1}$ & $\mathbf{0 . 8 7 8}$ & 0.562 & $\mathbf{0 . 6 4 7}$ & $\mathbf{0 . 7 6 4}$ & & \\
WTT & 0.078 & 0.305 & 0.077 & 0.381 & 0.556 & 0.299 & 0.050 & \\
Overlap & $0.729 \pm$ & $0.704 \pm$ & $0.732 \pm$ & $0.690 \pm$ & $0.730 \pm$ & $0.731 \pm$ & $0.653 \pm$ & $0.249 \pm$ \\
(mean \pm SD) & 0.307 & 0.185 & 0.297 & 0.166 & 0.110 & 0.195 & 0.300 & 0.190 \\
& & & & & & & & \\
\hline
\end{tabular}


Table 5. Anous stolidus, Sterna fuscata and Phaethon lepturus. Diet composition (numerical frequencies of the principal prey families consumed) of brown noddy, sooty tern and white-tailed tropicbird chicks on Aride and Cousin islands during different seasons. $\mathrm{SE}=\mathrm{SE}$ monsoon, $\mathrm{NW}=\mathrm{NW}$ monsoon, $\mathrm{n}=$ number of prey

\begin{tabular}{|c|c|c|c|c|c|c|c|c|c|c|c|}
\hline \multirow[t]{2}{*}{ Prey } & \multicolumn{3}{|c|}{- Brown noddy -} & \multicolumn{3}{|c|}{ - Sooty tern } & \multicolumn{5}{|c|}{ White-tailed tropicbird } \\
\hline & $\begin{array}{l}\text { SE } 2005 \\
(n=633)\end{array}$ & $\begin{array}{l}\text { SE } 2006 \\
(n=319)\end{array}$ & $\begin{array}{l}\text { SE } 2007 \\
(n=347)\end{array}$ & $\begin{array}{l}\text { SE } 2005 \\
(n=303)\end{array}$ & $\begin{array}{l}\mathrm{SE} 2006 \\
(\mathrm{n}=325)\end{array}$ & $\begin{array}{l}\text { SE } 2007 \\
(n=282)\end{array}$ & $\begin{array}{l}\mathrm{SE} 2005 \\
(\mathrm{n}=242)\end{array}$ & $\begin{array}{l}\text { SE } 2006 \\
(n=246)\end{array}$ & $\begin{array}{l}\text { SE } 2007 \\
(\mathrm{n}=254)\end{array}$ & $\begin{array}{l}\text { NW } 2006 \\
(n=64)\end{array}$ & $\begin{array}{r}\text { NW } 2007 \\
(\mathrm{n}=233)\end{array}$ \\
\hline Hemiramphidae & 0.6 & 2.2 & 0.0 & 0.7 & 1.2 & 0.0 & 12.8 & 15.9 & 7.5 & 7.8 & 5.6 \\
\hline Exocoetidae & 3.5 & 3.8 & 1.2 & 10.9 & 5.5 & 2.1 & 20.3 & 17.9 & 15.8 & 28.1 & 21.0 \\
\hline Coryphaenidae & 0.2 & 0.6 & 0.3 & 0.7 & 0.6 & 0.0 & 4.1 & 4.1 & 3.2 & 3.1 & 6.9 \\
\hline Scombridae & 2.7 & 2.2 & 4.9 & 13.2 & 5.2 & 12.8 & 4.6 & 11.4 & 18.9 & 4.7 & 1.3 \\
\hline Carangidae & 5.2 & 1.9 & 24.8 & 9.9 & 1.9 & 20.6 & 19.4 & 8.5 & 12.6 & 6.3 & 8.6 \\
\hline Caesionidae & 2.5 & 1.9 & 0.9 & 3.3 & 2.5 & 0.0 & 1.7 & 2.0 & 2.4 & 0.0 & 6.9 \\
\hline Mullidae & 31.6 & 9.1 & 47.3 & 26.7 & 38.7 & 40.8 & 2.5 & 0.8 & 3.5 & 1.6 & 0.9 \\
\hline Engraulidae & 24.3 & 3.8 & 7.2 & 7.6 & 0.9 & 2.5 & 0.0 & 0.0 & 1.6 & 0.0 & 1.7 \\
\hline Clupeidae & 0.8 & 0.6 & 7.2 & 1.0 & 1.2 & 13.5 & 1.2 & 3.3 & 3.9 & 0.0 & 0.0 \\
\hline Fish larvae & 10.6 & 46.4 & 2.6 & 0.0 & 2.8 & 0.0 & 0.0 & 0.0 & 0.0 & 10.9 & 0.0 \\
\hline Others & 0.2 & 0.0 & 0.0 & 0.0 & 3.7 & 2.5 & 0.4 & 0.8 & 1.6 & 0.0 & 4.7 \\
\hline Unidentified fish & h 6.9 & 8.2 & 1.7 & 8.9 & 6.8 & 0.0 & 8.3 & 3.3 & 1.2 & 4.7 & 1.3 \\
\hline Squid & 10.9 & 19.1 & 2.0 & 17.2 & 28.9 & 5.3 & 24.8 & 30.9 & 27.9 & 32.8 & 41.2 \\
\hline Crustacea & 0.0 & 0.3 & 0.0 & 0.0 & 0.0 & 0.0 & 0.0 & 1.2 & 0.0 & 0.0 & 0.0 \\
\hline
\end{tabular}

White-tailed tropicbird and white tern were the only species sampled during both the SE and NW monsoons. Differences in the diet of white-tailed tropicbirds between the 2 seasons were small, but it seems that overall, tropicbirds consumed smaller amounts of Carangidae and Scombridae during the NW monsoon (Fig. 2, Table 5). Seasonal differences in the diet of white terns were not apparent from the PCA. However, white terns showed a more diverse diet composition during the NW monsoon, with a less marked dominance of Mullidae and a higher number of fish families and of unidentified fish (Table 6).
The growth curves of lesser noddy chicks for the 3 breeding seasons studied are presented in Fig. 3. The linear growth rate of lesser noddy chicks in 2006 (1.92 $\pm 1.09 \mathrm{~g} \mathrm{~d}^{-1}$ ) was significantly lower than that in 2005 $\left(3.85 \pm 0.61 \mathrm{~g} \mathrm{~d}^{-1}\right)$ and 2007 (3.95 $\pm 0.77 \mathrm{~g} \mathrm{~d}^{-1}$; KruskalWallis $\left.\chi_{(2)}^{2}=86.30, \mathrm{p}<0.001\right)$. The decline in chick growth in 2006 was synchronised for most of the sampled birds, starting approximately on 28 July and extending until the 3rd wk of August. During this period, $44 \%$ of the studied lesser noddy chicks $(n=37)$ died of starvation.
Table 6. Gygis alba. Diet composition (numerical frequency) of white tern chicks on Aride Island during 5 seasons. SE $=\mathrm{SE}$ monsoon, $\mathrm{NW}=\mathrm{NW}$ monsoon, $\mathrm{n}=$ number of prey

\begin{tabular}{|lccccc|}
\hline Prey & $\begin{array}{r}\text { SE 2005 } \\
(\mathrm{n}=89)\end{array}$ & $\begin{array}{c}\text { SE 2006 } \\
(\mathrm{n}=88)\end{array}$ & $\begin{array}{r}\text { SE 2007 } \\
(\mathrm{n}=96)\end{array}$ & $\begin{array}{c}\text { NW 2006 } \\
(\mathrm{n}=160)\end{array}$ & $\begin{array}{c}\text { NW 2007 } \\
(\mathrm{n}=187)\end{array}$ \\
\hline Mullidae & 43.8 & 53.4 & 74.0 & 31.9 & 39.0 \\
Scombridae & 10.1 & 0.0 & 2.1 & 1.3 & 0.0 \\
Belonidae & 0.0 & 0.0 & 0.0 & 0.0 & 10.7 \\
Exocoetidae & 11.2 & 17.1 & 5.2 & 6.9 & 8.6 \\
Hemiramphidae & 3.4 & 3.4 & 0.0 & 5.0 & 2.1 \\
Caesionidae & 5.6 & 2.3 & 0.0 & 1.3 & 2.1 \\
Holocentridae & 0.0 & 0.0 & 0.0 & 1.3 & 0.5 \\
Carangidae & 0.0 & 2.3 & 3.1 & 7.5 & 3.7 \\
Engraulidae & 0.0 & 0.0 & 0.0 & 0.6 & 1.6 \\
Clupeidae & 0.0 & 0.0 & 0.0 & 0.0 & 1.6 \\
Coryphaenidae & 0.0 & 0.0 & 0.0 & 0.0 & 0.5 \\
Pomacentridae & 0.0 & 0.0 & 0.0 & 0.0 & 1.1 \\
Fish larvae & 0.0 & 0.0 & 0.0 & 7.5 & 0.0 \\
Unidentified fish & 16.9 & 15.9 & 9.4 & 31.9 & 21.4 \\
Squid & 9.0 & 5.7 & 6.3 & 5.0 & 7.0 \\
\hline
\end{tabular}

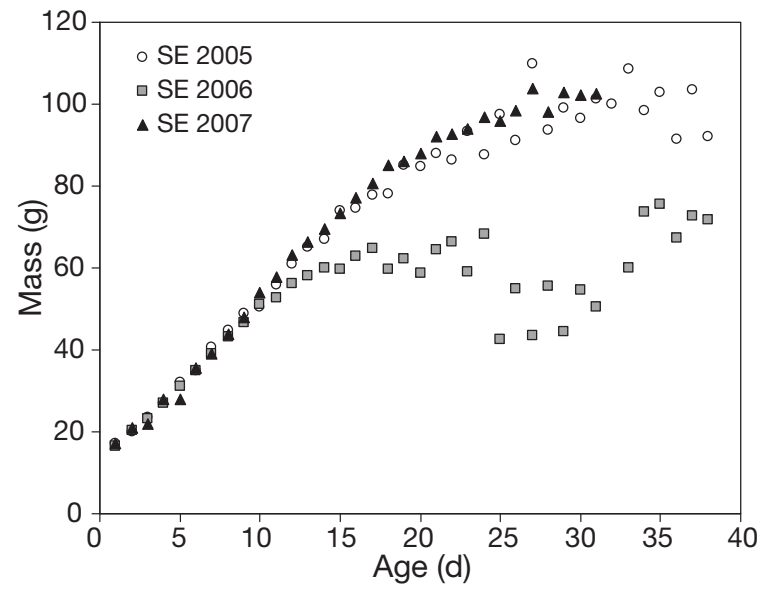

Fig. 3. Anous tenuirostris. Comparison of chick growth (mean) on Aride Island between the SE monsoons of 2005, 2006 and 2007. Sample sizes (n) differ for different chick ages: $\mathrm{n} \min =1, \mathrm{n} \max =42$, median $=17$ in 2005 ; $\mathrm{n} \min =1, \mathrm{n} \max =55$, median $=40$ in 2006; $\mathrm{n} \min =1, \mathrm{n} \max =27$, median $=18$ in 2007 
During the SE monsoon of 2006, we found evident differences in the diet composition of brown noddies, sooty terns and white terns before and during the environmental perturbation that negatively affected lesser noddy chicks, whereas lesser noddies and white-tailed tropicbirds showed comparatively smaller differences in the proportion of prey consumed between the 2 periods (Fig. 4). Mullidae, the most consumed prey for most species, virtually disappeared from the diet of brown noddies and sooty terns, and declined in the diet of white terns during the period of environmental perturbation to less than half of its value beforehand (Fig. 4). Lesser noddies, on the contrary, kept on feeding on Mullidae. Carangidae and Scombridae, prey that were overall less consumed, were also rarely consumed during the period of environmental perturbation. On the other hand, the frequency of Exocoetidae increased in the diet of white terns, the frequency of fish larvae increased in the diet of lesser and brown noddies and the frequency of squid increased in the diet of brown noddies and sooty terns (Fig. 4).

-Before environmental perturbation
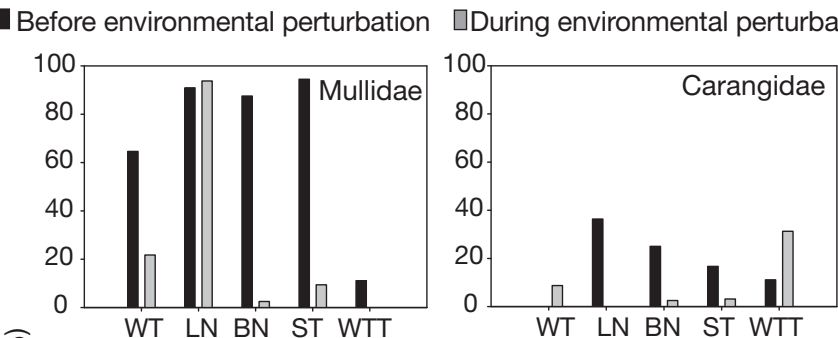

응
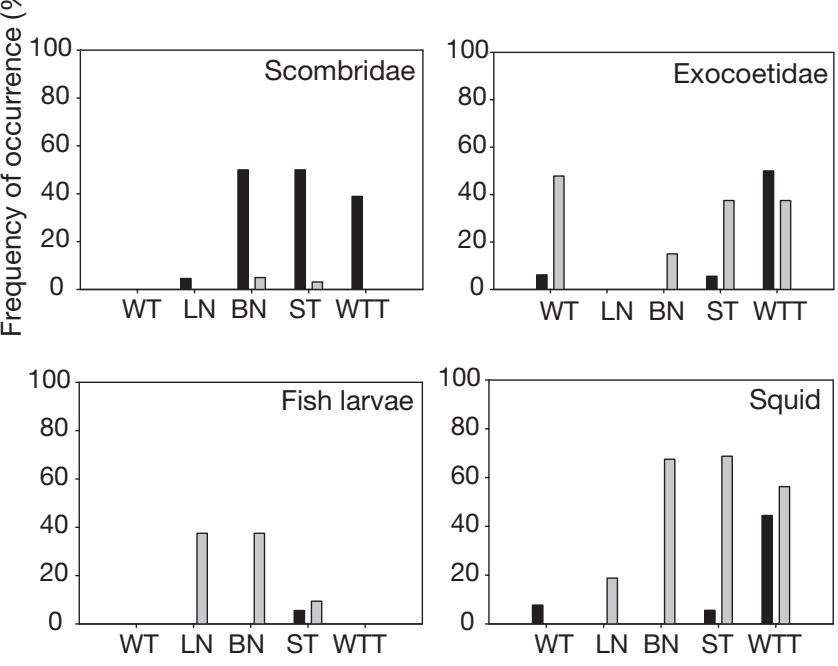

Fig. 4. Gygis alba, Anous tenuirostris, A. stolidus, Sterna fuscata and Phaethon lepturus. Differences in the frequency of occurrence $(\%)$ of the principal prey taxa in the diet of white tern (WT), lesser noddy (LN), brown noddy $(\mathrm{BN})$, sooty tern (ST) and white-tailed tropicbird (WTT), on Aride Island, before and during the environmental perturbation that affected growth and survival of lesser noddy chicks

\section{Prey length}

Mean length and length frequency distributions of fish prey taken by the seabirds are presented in Fig. 5 (no data on fish biometrics are available for shearwaters given that items were too digested for accurate measurements of their length or weight). Overall, there was a significant segregation in the size of fish prey consumed $\left(F_{5,1653}=721.1, \mathrm{p}<0.001\right)$, with white-tailed tropicbirds consuming the larger fish $(127.7 \pm 40.1 \mathrm{~mm}, \mathrm{n}=291)$, followed by sooty terns and brown noddies with similar prey lengths $(70.7 \pm 19.0 \mathrm{~mm}, \mathrm{n}=104$ and $70.0 \pm$ $22.0 \mathrm{~mm}, \mathrm{n}=129$, respectively), lesser noddies and roseate terns with similar prey lengths $(45.9 \pm 11.5 \mathrm{~mm}$, $\mathrm{n}=342$ and $46.2 \pm 11.8, \mathrm{n}=221$, respectively) and white terns feeding their chicks with smaller prey (33.5 \pm $19.5 \mathrm{~mm}, \mathrm{n}=568$ ). Mullidae length was also significantly different among species $\left(F_{5,936}=136.1, \mathrm{p}<0.001\right.$, followed by post hoc Tukey tests) and followed approximately the same pattern just described (white-tailed tropicbird: no data; sooty tern: $72.5 \pm 10.2 \mathrm{~mm}, \mathrm{n}=70$; brown noddy: $58.2 \pm 12.6 \mathrm{~mm}, \mathrm{n}=75$; roseate tern: $44.9 \pm$ $11.0 \mathrm{~mm}, \mathrm{n}=200$; lesser noddy: $44.7 \pm 11.1 \mathrm{~mm}, \mathrm{n}=306$; white tern: $30.1 \pm 13.4 \mathrm{~mm}, \mathrm{n}=280$ ). We found a significant positive correlation between mean adult body mass and mean prey length $(r=0.943, \mathrm{p}<0.01)$, with larger birds consuming larger prey (Fig. 6).

\section{Chick feeding schedules}

Feeding schedules of lesser noddy and white-tailed tropicbird chicks were similar between sampling seasons $\left(\chi_{(4)}^{2}=5.85\right.$ and $\chi_{(8)}^{2}=14.63, p=n s$, respectively; Fig. 7). Lesser noddies fed their chicks during the whole daylight period (Fig. 7). White-tailed tropicbirds fed their chicks mainly in the morning, before 11:00 h, and early afternoon (Fig. 7). Feeding schedules of brown noddy and sooty tern chicks were significantly different among sampling seasons $\left(\chi^{2}{ }_{(6)}=\right.$ 87.37 and $\chi_{(3)}^{2}=16.92$, $p<0.001$, respectively; Fig. 7). Brown noddies showed the largest annual variation in feeding schedules. In 2005 and 2007, feeding events occurred almost equally during the daylight and night periods. In 2006, during the period of environmental perturbation that affected growth and survival of lesser noddy chicks, most feeding events took place at night and the percentage of meal deliveries for the period 24:00 to 06:00 $\mathrm{h}$ reached a maximum (Fig. 7). Sooty terns fed their chicks mainly during the daylight period, until 18:00 h. Differences between 2005 and 2006 refer mainly to the higher number of meals delivered during the morning period in 2006 and to the lower number during the night, between 18:00 and 24:00 h (Fig. 7). 

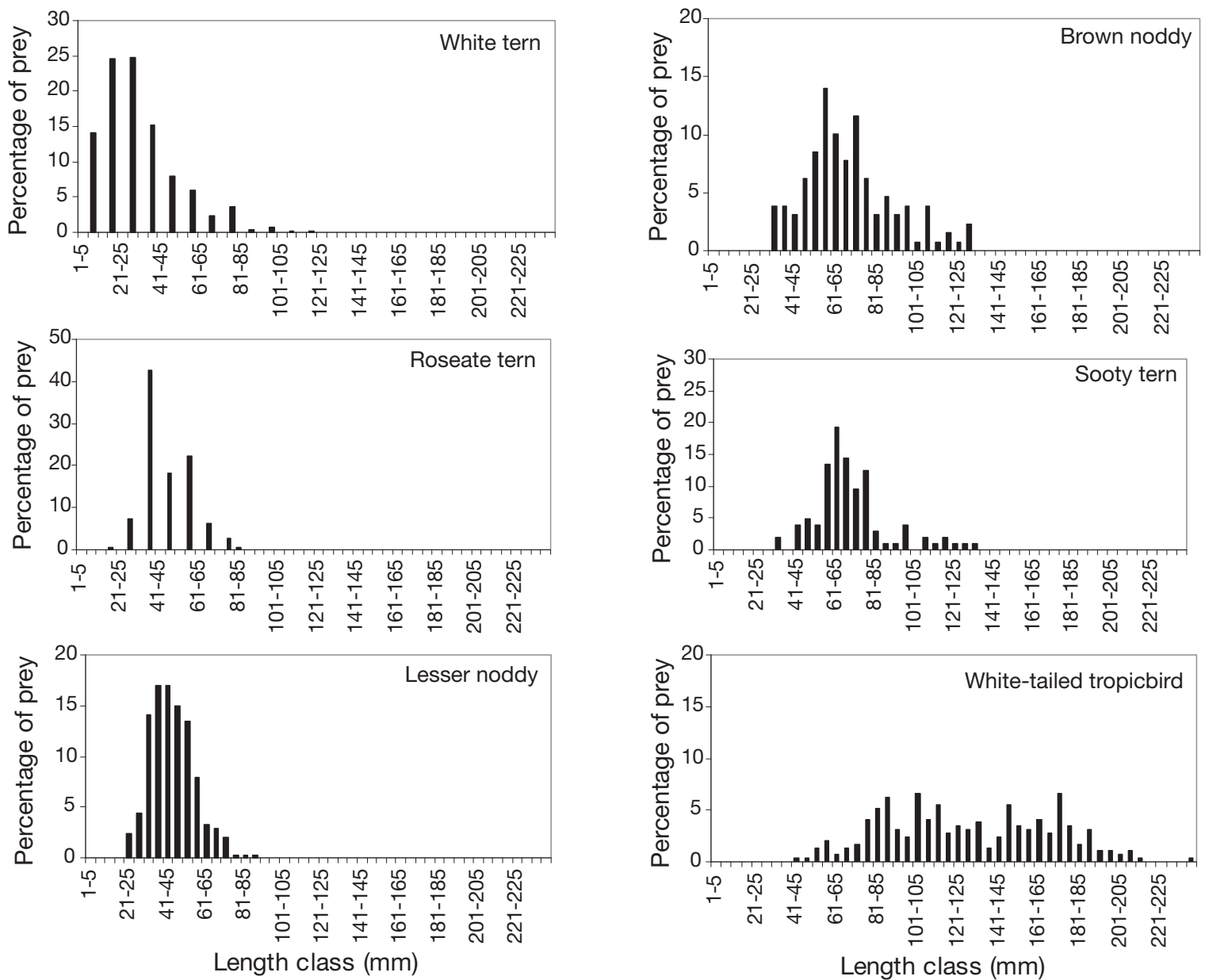

Fig. 5. Gygis alba, Sterna dougallii, Anous tenuirostris, A. stolidus, S. fuscata and Phaethon lepturus. Percentage frequency distribution and mean of fish prey lengths (TL) present in the diet

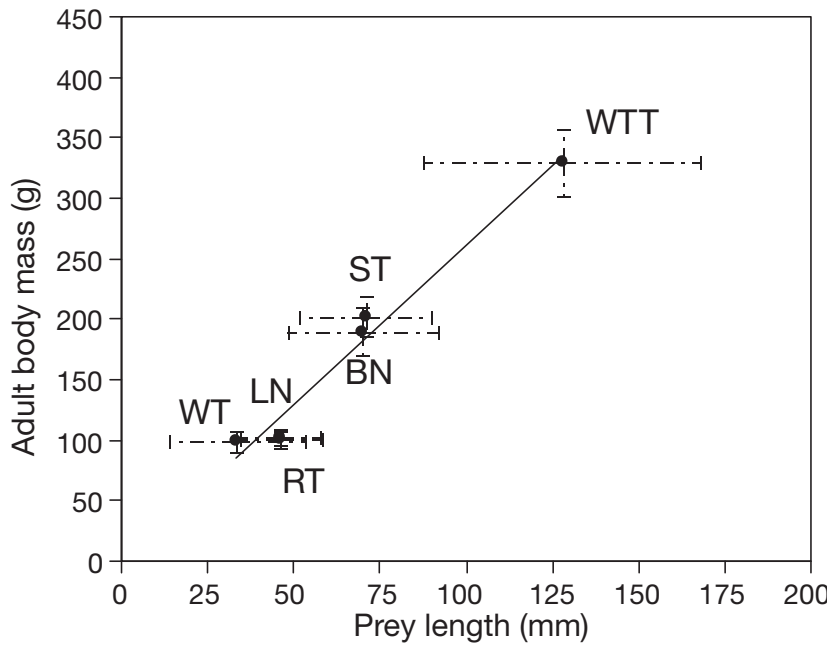

Fig. 6. Gygis alba, Sterna dougallii, Anous tenuirostris, A. stolidus, S. fuscata and Phaethon lepturus. Relationship between mean adult body mass and mean prey length (TL) per food sample $(r=0.943, p=0.005)$. Variance bars refer to SD. $\mathrm{LN}=$ lesser noddy, $\mathrm{BN}=$ brown noddy, $\mathrm{ST}=$ sooty tern, $\mathrm{WT}=$ white tern, RT = roseate tern, WTT = white-tailed tropicbird

\section{DISCUSSION}

\section{Diet composition and foraging behaviour}

Diet composition of the seabird community of Aride and Cousin islands was overall less diverse (low number of prey families and/or species and higher dominance of the most consumed prey) than that found in other tropical communities, such as those of Hawaii, Pacific Ocean (Harrison et al. 1983), and of the Houtman Abrolhos island group, eastern Indian Ocean (Surman \& Wooller 2003). However, similarly to what was found in other tropical breeding localities, seabirds from the Seychelles consumed mainly pelagic juvenile fish, such as Mullidae, Exocoetidae, Carangidae, Scombridae and Engraulidae, and Ommastrephid squids (Brown 1975, Harrison et al. 1983, Surman \& Wooller 2003, Spear et al. 2007, Jaquemet et al. 2008). A few fish families, such as Gonorhynchidae (beaked salmons) and Nomeidae (driftfishes), important in the diet of several terns in other areas of the Indian Ocean 

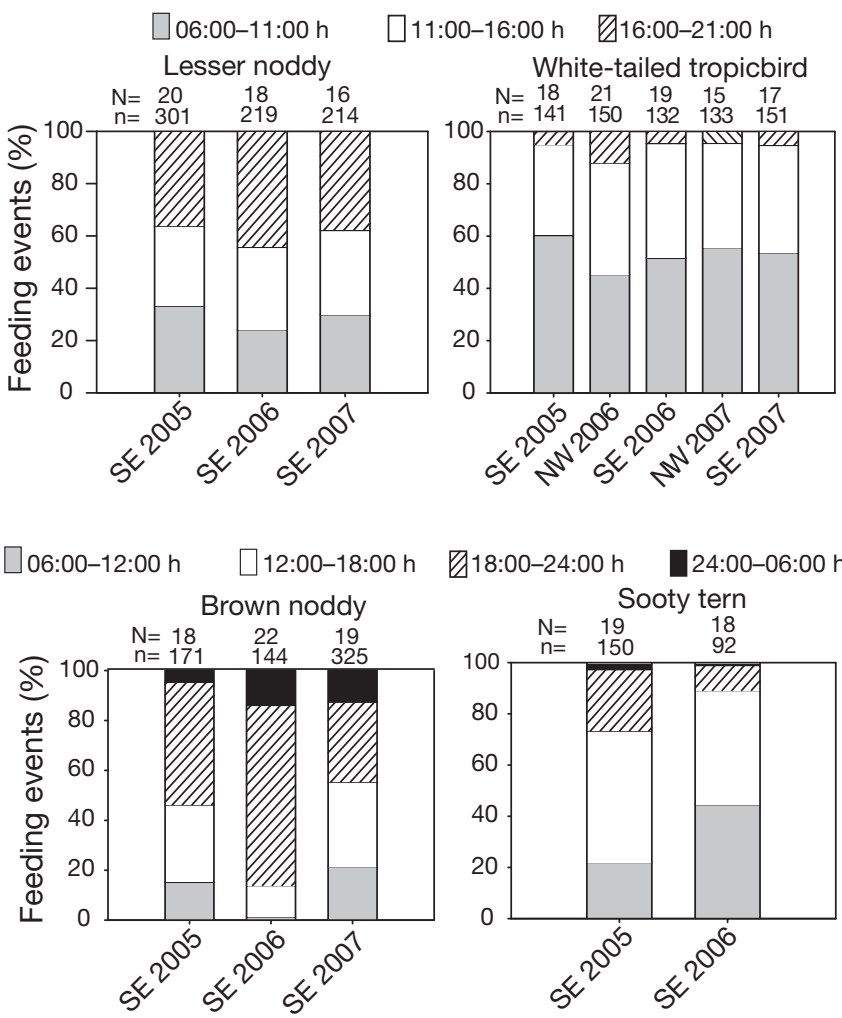

Fig. 7. Anous tenuirostris, Phaethon lepturus, A. stolidus and Sterna fuscata. Chick feeding schedules on Aride Island in different seasons (SE: SE monsoon, NW: NW monsoon) and years. Chicks were weighed 4 times each day: lesser noddies and white-tailed tropicbirds at 06:00, 11:00, 16:00 and 21:00 h, and brown noddies and sooty terns at 06:00, 12:00, 18:00 and 24:00 h. Number of chicks sampled $(\mathrm{N})$ and number of

feeding events (n) are presented at the top of each bar

(Surman \& Wooller 2003, Jaquemet et al. 2008), were not found in our samples. Overall, Mullidae and squid seem to be the most important prey items for these 8 tropical seabirds, both in the Indian and Pacific oceans (Brown 1975, Diamond 1983, Harrison et al. 1983, Surman \& Wooller 2003, Spear et al. 2007, Jaquemet et al. 2008).

Overlap indices were extremely high within the community studied (except for white-tailed tropicbird), underlying the similarity in diet composition between species. Indeed, juvenile fish from the Mullidae family dominated the diet of 7 of the 8 studied species. The low consumption of Mullidae by white-tailed tropicbirds might be related to the foraging strategy of both prey and predator. Mullidae are carnivorous benthic reef fishes, but the juveniles undergo a pelagic planktivorous phase (Smith \& Heemstra 1986) being available as prey to seabirds. Within the seabird community studied, white-tailed tropicbirds consumed the larger prey items; presumably, mullids matching the preferential prey size for tropicbirds are no longer pelagic. On the other hand, the white-tailed tropicbird is the only species studied which is almost exclusively solitary when foraging, and frequently forages without any association with sub-surface predators (Feare 1981, Jaquemet et al. 2004). Therefore, if the availability of Mullidae for seabirds is dependent on the presence of sub-surface predators, as suggested by the diet and foraging behaviour of most of these seabird species, only occasionally would tropicbirds be able to prey upon these fish.

In contrast to the high consumption of Mullidae by flock-feeding seabirds, pelagic fish predators (yellowfin and bigeye tunas, swordfish and lancetfish) do not prey upon mullids in the western Indian Ocean (Potier et al. 2004, 2007). These results might be explained because (1) prey studied by Potier et al. (2004, 2007) were caught mainly in offshore and deeper areas outside the Seychelles Bank ('plateau') area, while most seabirds tend to forage in more inshore and shallow areas (authors' unpubl. data), (2) Mullidae become available to foraging seabirds as a result of the presence of the cited predatory fish, even if they are not target prey for those fish or (3) seabirds of Aride and Cousin islands are preferentially associated with other (not included in Potier et al. 2004, 2007) sub-surface predators. In fact, at-sea surveys made in the Seychelles have shown that flocks of lesser noddies and white terns feed mostly within the limits of the 'plateau' in associations with groups of surfacedwelling carangids such as Selar spp., while sooty terns and shearwaters flocks forage further from the island in association with skipjack and yellowfin tunas (S. Jaquemet unpubl. data). Spear et al. (2007) also failed to link seabird and tuna diets in the eastern tropical Pacific Ocean.

In common with other studies (Diamond 1983, Harrison et al. 1983, Surman \& Wooller 2003), we found that offshore foraging species (white-tailed tropicbird, sooty tern and wedge-tailed shearwater) consumed more squid than intermediate or inshore foraging species (although brown noddies may consume considerable proportions of cephalopods during periods of low availability of Mullidae - see 'Inter-annual and seasonal variations in diet composition' below). However, and contrary to what we recorded, several authors have found that diets of offshore feeding species were less diverse and showed higher overlap than those of inshore species (although some communities studied included larger-bodied offshore feeders; Diamond 1983, Harrison et al. 1983, Surman \& Wooller 2003).

Diet segregation on the basis of prey length, which was found for both offshore and inshore feeding species, is presumably an important factor to avoid competition for food resources. The extent of segregation in terms of foraging habitats is, however, less evident. 
Jaquemet et al. (2004) showed that the seabird community around Réunion Island in the southwest Indian Ocean was strongly structured according to distance to the shore and bathymetry. The Seychelles archipelago is situated on a continental shelf, the Seychelles Bank, and the uniformity of the marine environment in this 'plateau' possibly prevents much foraging habitat specialisation by the species that exploit this area. Typically offshore foraging species, such as white-tailed tropicbirds, sooty terns and wedge-tailed shearwaters, are able to travel several hundreds of kilometres and leave the 'plateau' to search for food in the deeper oceanic waters. However, the high overlap in diet composition (except for tropicbirds) found in the present study suggests that most species exploit similar foraging habitats and/or that prey diversity is low in the study area. The lower overlap in diet between whitetailed tropicbirds and the former species might be related to differences in behavioural feeding strategies (as explained above in this section).

Nocturnal feeding is usually rare among tropical seabirds, but it has been confirmed with direct observations for wedge-tailed shearwaters and sooty terns (Gould 1967). In contrast to what was found in Hawaii (Brown 1975), sooty terns and brown noddies of Aride Island fed their chicks mainly during the daylight period and early at night, respectively, suggesting that these species forage essentially during the daylight period, as in the Mozambique Channel (S. Jaquemet et al. unpubl. data).

\section{Inter-annual and seasonal variations in diet composition}

Despite the high dietary overlap, inter-annual changes in diet composition recorded in the present study were not generalised within the community. During the SE monsoon of 2007, the percentages of Clupeidae, Carangidae and Scombridae increased in the diet of some species but remained virtually unchanged in the diet of others. Interestingly, the higher consumption of these 3 prey families was reflected mainly in the diet of the larger seabird species, suggesting that the presumably higher abundance of those prey was mainly restricted to certain size-classes, preferentially taken by larger birds. The incomplete sampling design in the present study (with some species being sampled in different islands in different years) could potentially have been insufficient to detect all dietary differences. Nevertheless, other studies have also found low inter-annual changes in the diet composition of tropical seabirds in the Indian Ocean (e.g. Le Corre et al. 2003, Jaquemet et al. 2008, Monticelli et al. 2008).
Dietary variations between monsoons were only studied in white-tailed tropicbirds and white terns. Diet composition of tropicbirds was similar during the 2 monsoon seasons, whereas white terns showed a more diverse diet, with a lower abundance of Mullidae, during the NW monsoon. Brown and lesser noddies breed in small numbers during the NW monsoon and thus the collection of a representative number of food samples was not possible. However, occasional observations of chick regurgitations during the NW monsoon in both 2006 and 2007 suggest that brown noddies consumed a larger amount of fish larvae in this season (T. Catry unpubl. data). Harrison et al. (1983) also found some seasonal variations in the diet of the seabird community of Hawaii, whereas Spear et al. (2007) found no evidence for a seasonal effect in the diet of seabirds of the eastern tropical Pacific Ocean.

The low breeding performance of lesser noddies on Aride Island in 2006, characterised by a sudden deterioration of chick growth rates and high chick mortality during August, suggests an abrupt decline in prey availability for this species. Several other observations not detailed here, such as the massive mortality of roseate terns during the first $2 \mathrm{wk}$ of August and the decline in chick growth rate of brown noddies and white terns in the same period (T. Catry unpubl. data), support the idea of a change in food availability. Comparisons of diet composition before and during the period of environmental perturbation that affected lesser noddies showed that brown noddies, sooty terns and white terns largely shifted their diets. Among the 4 seabird species that usually consume Mullidae as the main prey, the only species that did not change diet composition during this period was the one that suffered severe chick mortality (fledging success of brown noddies, sooty terns and white terns was similar to that of 2005 and 2007; T. Catry unpubl. data). Altogether, these results suggest that the environmental perturbation recorded was characterised mainly by a strong decline in the availability of Mullidae (instead of a potential increase in the availability of other prey, such as squid, Exocoetidae or fish larvae). Given that lesser noddies were unable to shift diet and prey upon another resource, only the individuals that managed to keep feeding on the low-availability Mullidae raised their chicks successfully. There are no data on the diet of roseate terns during the breeding season of 2006. However, the present study and others (Ramos 2000, Monticelli et al. 2008) have shown that roseate terns feed their chicks almost exclusively with Mullidae and, consequently, breeding success is highly dependent on the abundance of this prey (Ramos 2000). The mortality of virtually all non-fledged roseate tern chicks during the first 2 wk of August 2006 suggests that, as happened with lesser noddies, roseate terns were unable to shift diet when Mullidae became less abundant. 
Other effects of the presumed change in food availability were recorded in chick feeding schedules. In 2006, brown noddies delivered significantly more meals later in the day. This suggests that prey was more difficult to find and/or that birds had to forage further from the colony. The fact that sooty terns fed their chicks earlier in the day in 2006 than in 2005 cannot be linked to the environmental perturbation, because their chick feeding schedules in 2006 were recorded earlier in the season. Lesser noddies and white-tailed tropicbirds did not show significant differences in chick feeding schedules in 2006, which seems to be in concordance with the absence of dietary changes in that season.

Overall, these data support the higher vulnerability of species with smaller foraging ranges and/or with lower ability to switch diet (such as lesser noddy and roseate tern) towards short-term changes in food availability compared with less range-restricted and/or more opportunistic (with higher diversity of prey taxa in diet and/or higher ability to switch diet) species (such as white-tailed tropicbird, brown noddy, sooty tern and white tern). Comparable differences in the vulnerability of breeding seabirds were described for temperate species in the North Sea (Furness \& Tasker 2000), where most seabird species feed mainly on sandeels Ammodytes marinus. When the sandeel stock fell, the coastal foraging seabirds were most affected but the species with long foraging ranges were able to cope with the sandeel shortage.

\section{Are seabirds of the Seychelles foraging within an unpredictable environment?}

In comparison with temperate or polar marine environments, tropical oceans are usually characterised by a less marked seasonal abundance in food resources (Harrison \& Seki 1987, Weimerskirch 2007) and, consequently, several seabird species are non-seasonal or protracted breeders. Nevertheless, in the Seychelles archipelago there is a clear seasonality in food availability, which seems to be directly related to phytoplankton blooms (Monticelli et al. 2007). Two phytoplankton blooms occur with some predictability each year: a small one between December and February, and the main one between May and August (Monticelli et al. 2007). As a consequence, and despite some inter-annual variation in egg-laying dates, the breeding seasons of most seabird species from the Seychelles seem to be quite predictable, as was already described for other tropical areas (Harrison et al. 1983, Le Corre 2001, Le Corre et al. 2003, Jaquemet et al. 2007). On Aride Island, roseate terns are able to adjust their breeding phenology to inter-annual variations in the timing of the May to August phytoplankton bloom (Monticelli et al. 2007), and there is a positive relationship between the number of roseate terns that attempt to breed and lower sea surface temperatures (Ramos et al. 2002). Given that the majority of seabirds breeding on Aride and Cousin islands rely mainly upon the same prey type - juvenile Mullidae fish — we may assume that, for the majority of birds, the factors that determine egg-laying dates are possibly the same as those described for roseate terns. This apparent annual predictability of food resources seems, however, insufficient to assure high productivity levels, at least in more inshore foraging species. Evidently, in years of generally low oceanic productivity, when the phytoplankton bloom is less apparent, birds may fail completely (Monticelli et al. 2007) or, in extreme cases, may even not lay (Ramos et al. 2002). However, even in years with a more typical phytoplankton bloom (see Monticelli et al. 2007, their Table 2) food availability within a breeding season may show either short or long oscillations (Ramos 2000, Ramos et al. 2004, the present study), affecting with lower or higher impact the breeding success of seabirds. In summary, food availability in the Seychelles archipelago seems to be predictable at a large (annual) temporal scale, but highly unpredictable at a small (intra-seasonal or daily) temporal scale.

Acknowledgements. We acknowledge the Island Conservation Society (ICS) and Nature Seychelles for permission to work on Aride and Cousin islands, respectively. D. Monticelli, I. Catry and R. Tiatousse provided valuable help during the fieldwork. L. Balance and 2 anonymous reviewers gave helpful comments on an early draft of the manuscript. T.C. was funded by a Portuguese doctoral grant from Fundação para a Ciência e Tecnologia (SFRH/BD/16706/2004). This work is part of a regional programme on seabirds as bioindicators of the marine environment, funded by the Western Indian Ocean Marine Science Association (Marine Science for Management Grant, MASMA/AG/2004/04), and by the Agence National pour la Recherche (Programme REMIGE - ANR Biodiversité 2005-011). This research was conducted with permission of the Seychelles Bureau of Standards, Republic of Seychelles.

\section{LITERATURE CITED}

Ashmole NP (1971) Seabird ecology and the marine environment. Avian Biol 1:223-286

Ashmole NP, Ashmole MJ (1967) Comparative feeding ecology of seabirds of a tropical oceanic island. Bulletin 24. Peabody Museum, Yale University, New Haven, CT

Bailey RS (1968) The pelagic distribution of sea-birds in the Western Indian Ocean. Ibis 110:493-519

Ballance LT, Pitman RL (1999) Foraging ecology of tropical seabirds. In: Adams NJ, Slotow RH (eds) Proc 22nd Int Ornithol Congr, Aug 1998, Durban. BirdLife South Africa, Johannesburg, p 2057-2071

Bowler J, Betts M, Bullock I, Ramos JA (2002) Trends in 
seabird numbers on Aride Island Nature Reserve, Seychelles 1988-2000. Waterbirds 25:26-38

Braithwaite CJR (1984) Geology of the Seychelles. In: Stoddart DR (ed) Biogeography and ecology of the Seychelles islands. W. Junk, The Hague, p 17-38

Brown WY (1975) Parental feeding of young sooty terns (Sterna fuscata (L.)) and brown noddies (Anous stolidus (L.)) in Hawaii. J Anim Ecol 44:731-742

Diamond AW (1978) Population size and feeding strategies in tropical seabirds. Am Nat 112:215-223

Diamond AW (1983) Feeding overlap in some tropical and temperate seabird communities. Stud Avian Biol 8:24-46

Diamond A, Prŷs-Jones RP (1986) The biology of terns nesting at Aldabra Atoll, Indian Ocean, with particular reference to breeding seasonality. J Zool 210:527-549

Duffy DC, Jackson S (1986) Diet studies of seabirds: a review of methods. Colon Waterbirds 9:1-17

Feare CJ (1981) Breeding schedules and feeding strategies of Seychelles seabirds. Ostrich 32:179-185

Fishpool LDC, Evans MI (2001) Important bird areas in Africa and associated islands. Birdlife International Series 11. Birdlife International, Cambridge

$>$ Furness RW, Birkhead TR (1984) Seabird colony distributions suggest competition for food supplies during the breeding season. Nature 311:655-656

Furness RW, Tasker ML (2000) Seabird-fishery interactions: quantifying the sensitivity of seabirds to reductions in sandeel abundance, and identification of key areas for sensitive seabirds in the North Sea. Mar Ecol Prog Ser 202: 253-264

Gould PJ (1967) Nocturnal feeding of Sterna fuscata and Puffinus pacificus. Condor 69:529

Harrison CS, Seki MP (1987) Trophic relationships among tropical seabirds at the Hawaiian Islands. In: Croxall JP (ed) Seabirds: feeding ecology and role in marine ecosystems. Cambridge University Press, Cambridge, p 305-326

Harrison CS, Hida TS, Seki MP (1983) Hawaiian seabird feeding ecology. Wildl Monogr 85:1-71

$>$ Jaquemet S, Le Corre M, Weimerskirch H (2004) Seabird community structure in a coastal tropical environment: importance of natural factors and fish aggregating devices (FADs). Mar Ecol Prog Ser 268:281-292

Jaquemet S, Le Corre M, Quartly GD (2007) Ocean control of the breeding regime of the sooty tern in the southwest Indian Ocean. Deep-Sea Res Part I 54:130-142

Jaquemet S, Potier M, Cherel Y, Kojadinovic J and others (2008) Comparative foraging ecology and ecological niche of a superabundant tropical seabird: the sooty tern Sterna fuscata in the southwest Indian Ocean. Mar Biol 155: 505-520

Le Corre M (2001) Breeding seasons of seabirds at Europa Island (southern Mozambique Channel) in relation to seasonal changes in the marine environment. J Zool (Lond) 254:239-249

Le Corre M, Cherel Y, Lagarde F, Lormée H, Jouventin P (2003) Seasonal and inter-annual variation in the feeding

Editorial responsibility: Yves Cherel,

Villiers-en-Bois, France ecology of a tropical oceanic seabird, the red-tailed tropicbird Phaethon rubricauda. Mar Ecol Prog Ser 255: 289-301

Monticelli D, Ramos JA, Quartly GD (2007) Effects of annual changes in primary productivity and ocean indices on breeding performance of tropical roseate terns in the western Indian Ocean. Mar Ecol Prog Ser 351:273-286

Monticelli D, Ramos JA, Tavares PC, Bataille B, Lepoint G, Devillers P (2008) Diet and foraging ecology of roseate terns and lesser noddies breeding sympatrically on Aride Island, Seychelles. Waterbirds 31:239-248

Potier M, Marsac F, Lucas V, Sabatié R, Hallier JP, Ménard F (2004) Feeding partitioning among tuna taken in surface and mid-water layers: the case of Yellowfin (Thunnus albacares) and Bigeye (T. obesus) in the western tropical Indian Ocean. Western Indian Ocean J Mar Sci 3:51-62

Potier M, Marsac F, Cherel Y, Lucas V, Sabatié R, Maury O, Ménard F (2007) Forage fauna in the diet of three large pelagic fishes (lancetfish, swordfish and yellowfin tuna) in the western equatorial Indian Ocean. Fish Res 83:60-72

Ramos JA (2000) Characteristics of foraging habitats and chick food provisioning by tropical roseate terns. Condor 102:795-803

Ramos JA, Pacheco C (2003) Chick growth and provisioning of surviving and non-surviving white-tailed tropicbirds (Phaethon lepturus). Wilson Bull 115:414-422

Ramos JA, Maul AM, Ayrton V, Bullock I and others (2002) Influence of local and large-scale weather events and timing of breeding on tropical roseate tern reproductive parameters. Mar Ecol Prog Ser 243:271-279

Ramos JA, Maul AM, Bowler J, Monticelli D, Pacheco C (2004) Laying date, chick provisioning and breeding success of lesser noddies on Aride Island, Seychelles. Condor 106:887-896

Ramos JA, Maul AM, Bowler J, Wood L and others (2006) Annual variation in laying date and breeding success of Brown Noddies on Aride Island, Seychelles. Emu 106: 81-86

Schreiber EA, Burger J (2001) Biology of marine birds. CRC Press, Boca Raton, FL

Shealer D (2001) Foraging behavior and food of seabirds. In: Schreiber EA, Burger J (eds) Biology of marine birds. CRC Press, Boca Raton, FL, p 137-177

Smith MM, Heemstra PC (eds) (1986) Smiths' sea fishes. Springer-Verlag, New York

Spear LB, Ainley DG, Walker WA (2007) Foraging dynamics of seabirds in the eastern tropical Pacific Ocean. Stud Avian Biol 35, Cooper Ornithological Society, Los Angeles, CA

StatSoft (2000) Statistica for Windows (computer program manual). StatSoft, Tulsa, OK

Surman CA, Wooller RD (2003) Comparative foraging ecology of five sympatric terns at a sub-tropical island in the eastern Indian Ocean. J Zool (Lond) 259:219-230

Weimerskirch H (2007) Are seabirds foraging for unpredictable resources? Deep-Sea Res Part II 54:211-223

Submitted: February 4, 2008; Accepted: August 27, 2008

Proofs received from author(s): November 17, 2008 